\title{
Efek Penambahan Minuman Air Jeruk Sambal (Citrus Microcarpa) Terhadap Performa Broiler
}

\author{
The effect of Inclution Native Orange Water (Citrus microcarpa) on Performance of Broiler
}

\author{
D. Setiawan dan R. Adisti \\ Prodi Peternakan, Fakultas pertanian, Universitas Tanjungpura \\ Email: duta.setiawan@faperta.untan.ac.id
}

\begin{abstract}
ABSTRAK
This research aim to determine the effect of native orange(Citrus microcarpa) to drink water onbody weight, feed consumtion and FCR (feed convertion rate). The variables in this study were body weight, feed consumption and feed conversion in broiler. The used materials were day old chick (DOC) strain CP707 as many as 80 birds, were placed in cages with size of $(5,5 \times 2,5 \times 2 \mathrm{~m})$ is partitioned into 20 units an each unit in the experiment with the contents of 4 chickens. Feed used is commercial feed. The method used completely randomized design (CRD), with 4 treatment and 5 replications. with level treatment P0 (commercial feed and $0 \%$ native orange for $1 \mathrm{~L}$ water), $\mathrm{P} 1$ (commercial feed and 0,4 native orange for $1 \mathrm{~L}$ water), P2(commercial feed and $0,8 \%$ native oramge for $1 \mathrm{~L}$ water) and $\mathrm{P} 3$ (commercial feed and 1,2\% native orange for $1 \mathrm{~L}$ water). Data were analyzed using analysis of variance at level $5 \%$ and followed by honesty significant different (HSD). The result showed treatment not significant with body weight, feed consumtion and FCR (feed convertion rate).
\end{abstract}

Keyword: Citrus microcarpa, broiler and performance

\begin{abstract}
ABSTRAK
Penelitian ini bertujuan untuk mengetahui pengaruh penambahan air jeruk sambal (Citrus microcarpa)yang merupakan sumber asam organik sebagai acidifier pada air minum terhadap performa ayam broiler. Variabel pada penelitian ini adalah pertambahan bobot badan, konsumsi pakan dan konversi pakan pada broiler. Materi yang digunakan adalah ayam umur 1 hari (DOC) strain CP 707 sebanyak 80 ekor yang ditempatkan dalam kandang berukuran $(5,5 \times 2,5 \times 2 \mathrm{~m})$ yang disekat menjadi 20 unit dengan setiap unit percobaan di isi 4 ekor broiler. Pakan yang digunakan adalah pakan komersial (BR10, BR11 dan BR12). Metode yang digunakan adalah rancangan acak lengkap (RAL), dengan 4 perlakuan dan 5 ulangan dengan taraf perlakuan $\mathrm{P} 0(0 \%$ jeruk sambal per $1 \mathrm{~L}$ air $)$, P1 $(0,4 \%$ jeruk sambal per $1 \mathrm{~L}$ air), P2 (0,8\% jeruk sambal per $1 \mathrm{~L}$ air) dan P3( $1,2 \%$ jeruk sambal per $1 \mathrm{~L}$ air $)$. Data yang diperoleh dianalisis menggunakan analisis sidik ragam (ANOVA) pada taraf $5 \%$ dilanjutkan dengan uji beda nyata jujur (BNJ). Hasil penelitian menunjukan bahwa perlakuan berpengaruh tidak nyata terhadap bobot badan, konsumsi pakan dan konversi pakan.
\end{abstract}

Kata kunci: Citrus microcarpa, broiler dan performa

\section{PENDAHULUAN}

Masyarakat Indonesia belum mengenal akan pentingnya kesehatan hal ini ditunjukkan dengan masih tingginya angka kematian masyarakat Indonesia akibat konsumsi lemak yang berlebih. Masyarakat di indonesia lebih mementingkan kuantitas dibandingkan kualitas oleh sebab itu peternak lebih belum membudidayakan broiler bebas lemak karena takut akan berdampak pada penurunan daya beli yang disebabkan oleh penurunan bobot badan.

Keadaan inilah menuntut nutrisionis untuk menghasilkan produk daging ayam yang berkualitas baik (Aman, Sehat, Utuh dan Halal) yaitu dengan kandungan lemak rendah, bebas dari residu antibiotic sehingga aman untuk dikonsumsi oleh manusia akan tetapi tetap memperhatikan performa broiler yaitu 
bobot badan, konsumsi pakan dan FCR sehingga tercipta hubungan yang saling menguntungkan antara peternak dan konsumen.

Haroen (2017) pada sistem produksi ternak unggas, penggunaan antibiotik sintetis telah banyak dilakukan terutama untuk tujuan mencapai pertumbuhan yang cepat. Pertumbuhan yang cepat sering diikuti dengan perlemakan yang tinggi hal inilah yang menimbulkan kemungkinan tingginya kandungan lemak dalam tubuh ternak. Perlu dilakukan usaha untuk menurunkan kadar lemak pada broiler dengan asam organik yang alami. Penggunaan air jeruk sambal Pontianak (Citrus microcarpa) dalam air minum broiler dapat menurunkan kadar lemak daging 14,8\% (Adisti, 2017).

Jeruk sambal mengandung senyawa aktif berupa fenol dan flavonoid (Ghafar et al., 2009). Menurut Junaidi (2011) buah jeruk sambal Pontianak memiliki kandungan asam sitrat sebanyak 2,81\%. Mernurut Fenita (2011) zat-zat aktif seperti asam sitrat, saponin, $\mathrm{V}$ it $\mathrm{C}$, flavonoid dan tannin dalam jeruk nipis mampu menurunkan akumulasi lemak. Penelitian ini bertujuan untuk mengetahui pengaruh dan taraf terbaik penambahan air jeruk sambal (Citrus microcarpa) pada air minum terhadap performa ayam broiler antara lain bobot badan, konsumsi pakan dan FCR.

\section{MATERI DAN METODE}

\section{Materi penelitian}

Penelitian ini menggunakan broiler strain CP-707 dengan berat 48 g/ekor sebanyak 80 ekor umur 1 hari (DOC) yang dipelihara sampai 35 hari. Pemeliharaan dilakukan menggunakan kandang litter yang disekat 20 petak sekam padi sebanyak 3 karung $50 \mathrm{~kg}$, lampu neon 5 watt sebanyak 20 buah, jeruk sambal sebanyak kurang lebih $4 \mathrm{~kg}$, vaksin tetes ND pakan ayam pedaging yang diproduksi dari PT. Charoen Pokphand Indonesia yaitu pakan fase stater sebanyak 2 karung $50 \mathrm{~kg}$, pakan fase grower sebanyak 4 karung $50 \mathrm{~kg}$, pakan fase finisher sebanyak 2 karung $50 \mathrm{~kg}$, desinfektan merek rodalon dan timbangan analitik.

\section{Metode penelitian}

Rancangan yang digunakan dalam penelitian ini adalah rancangan acak lengkap (RAL) dengan 4 perlakuan dan 5 ulangan, sehingga terdapat 20 unit percobaan dengan tiap unit terdiri atas 4 ekor broiler. Taraf perlakuan yang diberikan berdasarkan modifikasi rancangan penelitian Jamilah. (2013) maka diperoleh perlakuan sebagai berikut:

P0 :Pakan komersial dan 0\% jeruk sambal per $1 \mathrm{~L}$ air

P1 :Pakan komersial dan 0,4\% jeruk sambal per $1 \mathrm{~L}$ air

P2 :Pakan komersial dan $0,8 \%$ jeruk sambal per $1 \mathrm{~L}$ air

P3 :Pakan komersial dan 1,2\% jeruk sambal per $1 \mathrm{~L}$ air

Air minum perlakuan dibuat dengan cara mencampurkan sari air jeruk sambal kedalam $1 \mathrm{~L}$ air minum kemudian diberikan kepada ayam adapun aturannya sebagai berikut:

P1 : $4 \mathrm{ml}$ sari air jeruk sambal dicampur ke dalam 1 liter air 
P2 : $8 \mathrm{ml}$ sari air jeruk sambal dicampur ke dalam 1 liter air

P3 : $12 \mathrm{ml}$ sari air jeruk sambal dicampur ke dalam 1 liter air

Pemeliharaan dilaksanakan selama 35 hari sedangkan perlakuan diberikan selama 4 minggu.

Bobot badan akhir didapat dengan cara penimbangan broiler pada waktu panen dengan mengambil satu persatu broiler kemudian ditimbang dan dicatat. Bobot badan akhir dinyatakan dalam g/ekor dan perhitungan dilakukan tiap perlakuan. Adapun perhitungan bobot badan akhir sebagai berikut:

Rata bobot badan akhir $=\frac{\text { jumlah bobot ayam }}{\text { jumlah ayam }}$

Konsumsi pakan merupakan jumlah pakan yang dikonsumsi tiap satu ekor ternak yang dinyatakan dala g/ekor. Konsumsi pakan dihitung setiap hari selama 35 hari kemudian dijumlahkan selanjutnya di rata-ratakan pada tiap perlakuan Adapun perhitungan rata-rata konsumsi pakan tiap perlakuan sebagai berikut:

konsumsi pakan $=\frac{\text { jumlah konsumsi pakan }}{\text { jumlah ayam }}$

Feed Convertion Rate (FCR) merupakan perbandingan antara konsumsi pakan dengan bobot badan akhir. Adapun perhitungan FCR sebagai berikut :

$$
F C R=\frac{\text { konsumsi pakan }}{\text { bobot badan akhir }} \times 100 \%
$$

Data yang diperoleh dianalisis menggunakan Analisis Sidik Ragam (ANOVA) pada taraf 5\% dan jika terdapat pengaruh nyata maka dilanjutkan dengan uji Beda Nyata Jujur (BNJ).

\section{HASIL DAN PEMBAHASAN}

Hasil penelitian tetang pengaruh penambahan air jeruk sambal (Citrus microcarpa) pada air minum broiler terhadap bobot badan akhir, konsumsi pakan dan FCR dapat dilihat pada Tabel dibawah ini :

Tabel 1 pengaruh penambahan air jeruk sambal (Citrus microcarpa) pada air minum broiler terhadap parameter perlakuan.

\begin{tabular}{lcccc}
\hline \multirow{2}{*}{ Parameter } & \multicolumn{4}{c}{ Perlakuan } \\
\cline { 2 - 5 } & P0 & P1 & P2 & P3 \\
\hline Bobot badan akhir (g/ekor) & $1458,90^{\mathrm{tn}} \pm 88,80$ & $1614,70^{\mathrm{tn}} \pm 62,40$ & $1567^{\mathrm{tn}} \pm 117,20$ & $1565^{\mathrm{tn}} \pm 41,80$ \\
Konsumsi pakan (g/ekor) & $2683,20^{\mathrm{t}} \pm 97,90$ & $2824,50^{\mathrm{tn}} \pm 111,2$ & $2739,5^{\mathrm{t}} \pm 103,2$ & $2710,5^{\mathrm{n}} \pm 87,10$ \\
FCR(\%) & $1,84^{\mathrm{tn}} \pm 0,13$ & $1,75^{\mathrm{tn}} \pm 0,06$ & $1,75^{\mathrm{tn}} \pm 0,10$ & $1,73^{\mathrm{tn}} \pm 0,09$ \\
\hline
\end{tabular}

Ket : Superskrip berarti $\mathrm{P}>0,05$ berpengaruh tidak nyata

\section{Bobot Badan Akhir}

Hasil analisis sidik ragam menunjukkan bahwa penambahan air jeruk sambal (Citrus microcarpa) pada air minum broiler tidak berpengaruh nyata terhadap bobot badan akhir broiler. Bobot badan akhir yang diperoleh dari penelitian ini berkisar antara
1458,90-1614,70 g/ekor. Agu et al. (2010) melaporkan hasil penelitaannya bahwa pertambahan bobot badan ayam broiler berkisar 0,9-1,54 kg yang memanfaatkan kulit buah jeruk manis (Citrus sinensis). Bobot badan dalam penelitian ini masih setara dengan penelitian Nisa (2003) bobot badan 
akhir broiler strain CP 707 umur 35 hari adalah 1513,30. Berdasarkan Tabel 1 diketahui bobot badan akhir perlakuan P0 dengan taraf $0 \%$ air jeruk sambal merupakan bobot badan akhir terendah jika dibandingkan dengan perlakuan lain dan dengan standar yang telah ditetapkan. Hal ini menunjukan bahwa air jeruk sambal memberikan pengaruh terhadap bobot badan akhir broiler walaupun tidak signifikan

Menurut Bell dan Weaver (2002), bobot badan akhir dipengaruhi oleh suhu lingkungan, konsumsi ransum, dan konversi ransum. Jumlah ransum yang dikonsumsi dan dikonversi tidak berbeda, disamping hal tersebut ayam dipelihara dalam suhu yang sama. Hal tersebut menyebabkan bobot badan akhir yang dicapai pada penelitian ini tidak berbeda

\section{Konsumsi Pakan}

Hasil analisis sidik ragam menunjukan bahwa penambahan air jeruk sambal (Citrus microcarpa) pada air minum broiler berpengaruh tidak nyata terhadap konsumsi pakan. Konsumsi pakan yang diperoleh pada penelitian ini berkisar 2683,2-2824,5 gram. Konsumsi pakan pada penelitian ini masih lebih tinggi dibandingkan dengan penelitian yang menanfaatkan by product jeruk yang hanya mengkonsumsi pakan berkisar 2152,22313,2 gram (Antogiovanni et al., 2005) . Rendahnya konsumsi pakan yang menggunakan by product jeruk karena broiler dipelihara di iklim subtropis dan tingkat streesnya rendah. Menurut standar konsumsi yang ditetapkan PT Charoen Pokphand, (2006) sebagai pedoman dilapangan technical service menunjukkan bahwa standar konsumsi ransum untuk strain Cp 707 adalah 2497,6 g/ekor untuk lima minggu pemeliharaan. Konsumsi pakan pada penelitian ini cenderung lebih tinggi dibandingkan dengan stardar yang ditetapkan oleh PT Charoen Pokphand. Berdasarkan Tabel 1. konsumsi pakan P0 merupakan konsumsi pakan terendah yaitu 2683,2 g/ekor dengan taraf pemberian air jeruk sambal $0 \%$, hal ini menunjukan bahwa air jeruk sambal dapat meningkatkan konsumsi pakan walaupun tidak signifikan, Terlepas dari hubungan konsumsi pakan dengan kandungan energi pakan, penelitian ini menggunakan penambahan air jeruk sambal pada air minum broiler sebagai acidifier. Jeruk sambal sebagai acidifier alami yang mengandung asam sitrat 2,8\% (Junaidi, 2008) pada penelitian ini juga memberikan sumbangsih yang positif karena meskipun memiliki ciri khas rasa yang asam, tidak menurunkan palatabilitas pakan, sehingga konsumsi pakan yang dihasilkan kurang lebih sama dengan kontrol. Hasil penelitian Natsir dan Sofjan (2008) juga memperlihatkan bahwa pada dasarnya acidifier tidak memperlihatkan pengaruh terhadap konsumsi pakan.

\section{Feed Convertion Rate (FCR)}

Hasil analisis sidik ragam menunjukan bahwa penambahan air jeruk sambal (Citrus microcarva) pada air minum broiler berpengaruh tidak nyata terhadap feed convertion rate. Adapun FCR yang diperoleh pada penelitian ini berkisar 1,73-1,84. Hasil penelitian ini masih lebih tinggi dibandingkan dengan penelitian yang memanfaatkan by product jeruk untuk pakan Broiler yaitu berkisar antara 1,57-1,72 (Antogiovanni et al., 2005). Penelitian penggunaan kulit buah jeruk 
manis kering menghasilkan FCR ayam broiler berkisar 1,67-1,98 (Ebrahimi et al., 2013). Manual Manajemen Broiler CP 707 (2005), menyebutkan bahwa konversi ransum ayam broiler CP 707 umur lima minggu dalam kondisi yang optimal dapat mencapai 1,69. Berdasrkan Tabel 1 diketahui bahwa P0 memiliki nilai FCR terbesar yaitu 1,84 (\%), Sedangkan pada P3 dengan penambahan air jeruk sambal 1,2 (\%) memiliki nilai FCR terkecil yaitu 1,73 (\%). Rasyaf (2011) berpendapat bahwa semakin kecil konversi ransum berarti pemberian ransum semakin efisien, namun jika konversi ransum tersebut membesar, maka telah terjadi pemborosan. Hal ini menunjukkan bahwa air jeruk sambal memberikan pengaruh terhadap efisensi pakan walaupun tidak signifikan.

Husmaini, (2000) menyatakan beberapa faktor utama yang mempengaruhi konversi ransum (FCR) adalah genetik, kualitas ransum, penyakit, temperatur, sanitasi kandang, ventilasi, pengobatan, dan manajemen kandang. Faktor pemberian ransum, penerangan juga berperan dalam mempengaruhi konversi ransum, laju perjalanan ransum dalam saluran pencernaan, bentuk fisik ransum dan komposisi nutrisi ransum, sementara itu pada penelitian ini ransum berasal dari ransum komersial yang memiliki kandungan nutrisi yang sama sehingga perbedaan konversi benar dipengaruhi secara tidak nyata oleh air jeruk sambal sebagai acidifier.

\section{KESIMPULAN}

Berdasarkan hasil penelitian ini dapat disimpulkan bahwa pemberian air jeruk sambal Pontianak pada air minum broiler tidak berpengaruh terhadap bobot badan, konsumsi pakan dan feed convertion rate (FCR).

\section{DAFTAR PUSTAKA}

Adisti, R. 2017. Pengaruh penambahan air jeruk sambal (Citrus Microcarpa) pada air minum terhadap kadal lemak daging broiler. Skripsi. Jurusan Peternakan Fakultas Pertanian Universitas Tanjungpura Pontianak.

Agu, P. N., O. I. A. Oluremi, and C. D. Tuleun. 2010. Nutritional evaluation of sweet orange (Citrus sinensis) friut peel as a feed resource in broiler production. International Journal of Poultry Science 9 (7): 684-688.

An-Nisa, Y. 2003. Pengamatan performa beberapa strain ayam broiler di Peternakan Cipinang Farm, Kecamatan Cimaung, Kabupaten Bandung. Skripsi. Fakultas Peternakan Institut Pertanian Bogor.

Antongiovanni, M., A. Buccioni, F. Petacchi, and A. Agnoletti. 2005. Use of a citrus by-product in broilers diets. Italian Journal Animal Science. 4 (2): 501503.

Ebrahimi, A., A. A. A. Qotbi, A. Seidavi, V. Laudadio, and V. Tufarelli. 2013. Effect of different levels of dried sweet orange (Citrus Sinensis) peel on broiler chickens growth performance. Journal of Archiv Tierzucht. 56 (2): 11-17.

Fenita, Y., O. Mega, dan E. Daniati. 2009. Pengaruh pemberian air nanas (Ananas comosus) terhadap kualitas daging ayam peterlur afkir. Jurnal Sain Peternakan Indonesia. 4 (1): 43-50.

Ghafar, M. K. 2010. Flavonoid hesperidine total phenolic contents and antioxidant activities from citrus spesies. African Journal of Biotechnology. 9, 326-330. 
Haroen, U. 2017. Penggunaan tepung limbah jus jeruk (Citrus sinensis) dalam ransum terhadap kualitas karkas ayam broiler. Jurnal Agripet. 17, 31-37

Husmaini. 2000. Pengaruh peningkatan level protein dan energi ransum saat refeeding terhadap performans ayam buras. Jurnal Peternakan dan Lingkungan. 6, 1-7

Jamilah, S. N. 2013. Peforma produksi dan ketahanan tubuh broiler yang diberi pakan step down dengan penambahan asam sitrat sebagai acidifier. Jurnal Fakultas Peternakan Universitas Diponegoro, 251-257.

Junaidi, A. 2011. Pengembangan produk unggulan jeruk kalamansi kota bengkulu dengan pendekatan ovop. Peneliti Madya Bidang Koperasi Pada Deputi Pengkajian Sumberdaya
UMKM Kementrian Koperasi dan UKM, Vol 19, 163-183.

Natsir, M. H. dan O. Sjofjan. 2008. Pengaruh penggunaan kombinasi asam sitrat dan asam laktat cair terenkapsulasi sebagai aditif pakan terhadap penampilan produksi ayam pedaging. Seminar Nasional Teknologi Peternakan dan Veteriner. 636-640.

PT Charoen Phokphand Indonesia. 2005. Manual Manajemen Broiler CP 707. Charoen Pokphand Indonesia, Jakarta.

PT. Charoen Phokphand Indonesia. 2006. Manajemen broiler modern. Kiat-kiat memperbaiki FCR. Technical Service and Development Department.

Rasyaf, M. 2011. Panduan beternak ayam petelur edisi ke XV. Yogyakarta: Kanisius. 